\title{
O OLHAR: JANELAS DA ALMA NA FICÇÃO MACHADIANA
}

\section{THE LOOK: WINDOWS OF THE SOUL IN THE MACHADIAN FICTION}

\author{
Norma de Siqueira Freitas ${ }^{\star}$
}

RESUMO: Machado de Assis - hábil na percepção do comportamento humano -, coloca-nos, através dos olhos de suas personas, a representação da vida moderna. Apresentamos aqui uma leitura sobre a tessitura dos olhos e do olhar na montagem do perfil das personagens dos contos: "Não é o mel para a boca do asno"; "O machete"; "Primas de Sapucaia!"; "Uma senhora”; "D. Paula”; “Trina e una”; “Conto de escola"; "Carolina"; "O caso da vara" e "Missa do galo".

PALAVRAS-CHAVE: olhos, perfil das personagens, contos.

ABSTRACT: Machado de Assis - good at understanding and portraying human behavior - gives us the representation of modern life through the eyes of his personas. We present here a reading on Machadian process of building eyes and looks to compose his characters' profiles in the following short stories: "Não é o mel para a boca do asno"; "O machete"; "Primas de Sapucaia!"; "Uma senhora"; "D. Paula"; "Trina e una"; "Conto de escola"; "Carolina”; "O caso da vara"; and "Missa do galo".

KEY WORDS: eyes, characters' profiles, short stories.

* Universidade Federal Fluminense. Niterói. RJ. Mestre em Literatura Brasileira. Doutoranda em Literatura Comparada do Programa de Pós-Graduação da UFF. Bolsista do CNPq. Email: normasfreitas@hotmail.com. 



\section{O OLHAR: JANELAS DA ALMA NA FICÇÃO MACHADIANA}

Não vês que o olho abraça a beleza do mundo inteiro? É a janela do corpo humano, por onde a alma especula e frui a beleza do mundo, aceitando a prisão do corpo que, sem esse poder, seria um tormento.

Leonardo da Vinci

Os olhos são vistos como espelhos da alma. Os antigos gregos os consideravam como portal de entrada, isto é, uma espécie de ponte a possibilitar a travessia entre o mundo real e o metafísico. Para eles, a visão era o mais importante e espiritual de todos os sentidos, já que fonte de sabedoria. O olho, então, como janela e espelho, seria o órgão responsável por receber e espalhar luz divina (lumina>fogo>divinização). No mundo cristão, a relação luz/Deus se mantém, uma vez que Deus é a luz do mundo: Luz/Verdade. Assim, o homem se enche de Verdade e a espalha a outro homem, sendo os olhos faróis dessa luminosidade; ou melhor, luz divina a espalhar-se sobre os corações dos humanos.

Na história do mundo e da cultura, várias são as lendas que fazem referência aos olhos. Narciso perde-se de si mesmo ao contemplar-se no espelho das águas. Orfeu vê perdida para sempre a imagem da bela Eurídice. Perseu induz Medusa a olhar para si mesma e, dessa forma, experimentar seu próprio veneno. A mulher de Ló olha para trás e, por isso, vira estátua de sal. Segundo relatos dos desbravadores do Novo Mundo, alguns indígenas 
seriam a própria imagem do medo, quando frente a um espelho acreditam ver a imagem refletida da alma.

Impossível negar que olhos são linguagem. Enquanto linguagem, podem enviar mensagens de amor ou ódio, de alegria ou tristeza. Como código expressivo, podem, ainda, penetrar no sensível campo da Literatura. Assim, corpos narrados pela arte da escrita adentraram pelo imaginário do leitor, alimentando sonhos e ilusões.

No romance moderno, filho dileto do cientificismo do século XIX, pequenos fragmentos corporais das criaturas de papel, como que visualizados através de lentes, passam a figurar, emitindo preciosos recados. Segundo Eugênio Gomes, quem primeiro explorou certas correspondências entre características físicas e características morais, nas personagens ficcionais, foi o escritor francês Honoré de Balsac, seguindo-se a este Dickens. (GOMES, 1967, p. 98). O escritor francês Gustave Flaubert, em especial, evidenciou largamente os olhos de suas personagens.

Como ilustração destacamos o excerto em que o romancista nos apresenta uma de suas personagens mais famosas, a frívola Ema Bovary, protagonista do romance Madame Bovary: "O que ela possuía de verdadeiramente belo eram os olhos; apesar de castanhos, pareciam pretos por causa das pestanas; o olhar era franco e de um arrojo cândido". (FLAUBERT, 1970, cap. III). A expressão final "arrojo cândido" nos apresenta um contraste, este nos aponta para uma aldeã provinciana, porém amante das grandes cidades. Aponta para uma mulher que confundira, "no desejo, a sensualidade do luxo com as alegrias do coração, a elegância dos hábitos com a delicadeza dos sentimentos." (Ibidem, cap. IX). Em Flaubert, como em Machado de Assis, aparecem mais olhos escuros que azuis.

$\mathrm{Na}$ Literatura Brasileira, o engenhoso romancista brasileiro, por meio da metáfora dos olhos e do olhar, permite-nos também conhecer os aspectos externos de suas personagens, assim como nos oferece a possibilidade de lhes perscrutar a alma. Tudo em Machado é intencional. É inegável a obsessão de MA pelos olhos, pois freqüentemente estes aparecem de forma inusitada; ora comunicando sensações e sentimentos, ora dialogando e executando ações importantes na trama, ora induzindo ao mistério.

Não é a cor dos olhos que lhe interessa, mas sim seu aspecto, a impressão causada, a expressividade, uma vez que chave significativa ao conhecimento dos heróis e vilões da prosa machadiana. Nela, os olhos agem, comunicam e refletem o mundo hipócrita, dominado pelas convenções sociais. Tais olhos 
denunciam a sociedade dantesca do Rio de Janeiro onde cobiça, soberba, luxúria, ira, vaidade, inveja, gula e dissimulação são uma constante.

Sabemos que o olhar mais estudado pelo mundo acadêmico é o da personagem Capitu, protagonista do romance D. Casmurro, de Machado de Assis. Os "olhos de ressaca" da heroína encerram mistério, ambigüidade traduzida pelos olhos misteriosos, "diretos e lúcidos", "crescidos e sombrios da cigana oblíqua”. São também os olhos que efetuam a ligação entre o interior e o exterior de Bento Santiago e, segundo a ensaísta Juracy Saraiva, em artigo disponível na Internet, "essa função é transferida aos olhos das outras personagens, diante das quais, ele [Bento] se situa como intérprete. Portanto, a ação de descrever o olhar reafirma caracteres do próprio protagonista" (2002).

Entretanto, não nos estenderemos mais na análise de D. Casmurro, posto que tal estudo tem sido tema recorrente em ensaios e livros. Nosso corpus será outro. Apresentaremos nossa leitura sobre os olhos em uma seleção de dez contos situados entre os anos de 1868 e 1894. Ei-los apontados: "Não é o mel para a boca do asno" (1868); "O machete" (1878); "Primas de Sapucaia!” (1883); "Uma senhora” (1883); “D. Paula” (1884); “Trina e una" (1884); "Conto de escola" (1884); "Carolina” (1886?); "O caso da vara” (1891); "Missa do galo" (1894).

Nossa análise não se prenderá ao olhar de Machado de Assis (algumas vezes, grafado MA), em relação à sua própria visão de mundo e nem se voltará para a análise do foco narrativo/ponto de vista da narrativa. A proposta central será uma leitura possível sobre a tessitura dos olhos/olhar na montagem do perfil das personagens machadianas. Nosso intento é demonstrar como o menino pobre do Morro do Livramento - contista e romancista -, foi hábil na percepção do homem e de seu comportamento diante da engrenagem das convenções sociais quando, com engenho e arte, colocou nos olhos de suas personagens os reflexos da alma humana subjugada aos jogos de interesse, ao poder, numa sociedade, onde só os mais fortes sobrevivem.

\section{Entre reflexos: pecados capitais}

A deusa da minha rua

Tem uns olhos donde a lua

Costuma se embriagar

Newton Teixeira/Jorge Faraj 
A obra de Machado pode ser encarada como documento da situação brasileira do século XIX. Nos contos (também nos romances e crônicas), é possível ver retalhos de uma sociedade burguesa e interesseira, cuja ideologia passa pelo desejo de possuir sempre mais. Nessa denúncia reside a universalidade de MA. É constante, em sua poética, o conflito entre essência e aparência, a aliança entre o popular e o erudito, apontando a angústia do inadaptado ao contexto social e às situações. Com pitadas de humor e, no mais das vezes, cortante ironia, o autor descortina sua opinião sobre o ridículo da vida e dos homens. Episódios aparentemente banais montam o painel da sociedade brasileira do fim de século. Uma sociedade que se dá a conhecer pelo olhar ora crítico, ora moralista de MA, olhar esse a se projetar nos olhos significativos, transparentes, enigmáticos, sonsos e agudos, puros e interesseiros das personagens de suas curtas narrativas. Desse modo, o artista, não vendo bondade no homem, oferece-nos uma fresta, uma pequena janela, para o conhecimento deste ser social desprezível e corruptível.

O genial escritor, de formação eminentemente romântica, domina o elevado, mas quando o transporta para sua criação literária, fá-lo no sentido de crítica irônica, isto observável, por exemplo, em "Um homem célebre", conto em que o escritor nos apresenta um Romantismo caricatural, uma vez que nos dá a conhecer Pestana, uma personagem de espírito romântico, um inadaptado, que traz em si o fracasso, perceptível também através dos reflexos de seus olhos. $\mathrm{Na}$ urdidura das palavras, curiosamente, há contos em que Machado tematizando a música e os instrumentos musicais, não deixa escapar, as expressivas imagens especulares percebidas através dos reflexos do olhar de suas criaturas de papel. Nesse caso estão os contos: "Um homem célebre", "Cantigas de esponsais" e "O machete", sendo o último foco inicial de nossas análises.

Em “O machete” (Contos/Uma antologia, 1998), a personagem Inácio enlouquece na tentativa de conciliar dois instrumentos musicais bastante simbólicos: o violoncelo (erudito) e o machete (o popular cavaquinho). Inácio, músico bem sucedido, é violoncelista exímio. O conflito acontece quando o tocador de cavaquinho conquista todos, inclusive, e principalmente, a mulher do músico exemplar. O desfecho se dá com a fuga de Carlotinha, motivo da loucura de nosso violoncelista.

Machado apresenta-nos Inácio como nascido para o violoncelo. Alheio a tudo, aparece somente impregnado de música, assim, transubstanciado 
em seu peculiar instrumento de corda. Se tal instrumento é representativo do idílio amoroso (no caso, do amor entre mãe e filho), uma curiosa associação é feita pelo escritor na montagem do protagonista. Ora, ao acabar de perder a mãe, transfere para Carlotinha a ligação afetiva tida com a falecida, visto que passa a tocar violoncelo para a esposa, como antes o fazia contemplativamente para a mãe. Na montagem do contista, Carlotinha era "uma mocinha de dezessete anos, parecendo dezenove, mais baixa que alta, rosto amorenado, olhos negros e travessos", que contrastavam com o olhar "branco e velado do marido" (MA, 1998, p. 244). Dessa forma, os olhos da moça, atados ao simbolismo do violoncelo, em contraste com os do pacífico marido, despontam a nos enviar recados.

Parece que o olhar "branco e velado" de Inácio opõe-se à informação subjacente ao próprio nome Inácio>Ignatius. Originário do latim, a denominação aponta para ardente; entretanto, o Inácio machadiano é um homem pacato, deprimido e inseguro, que de ardente nada tem. Outros elementos da montagem do casal reforçam os aspectos do contraste inicial dos olhos do casal, uma vez que apresenta Carlotinha como "faceira e amiga de brilhar" (p. 245), imagem bem diversa do apático Inácio, sempre voltado para a introspecção do espírito. A beleza de "olhos negros e travessos" era toda a riqueza de Carlotinha, enquanto a depressão/ausência da mãe era tudo que restava a nosso protagonista. A índole da mulher jovial, num jogo pendular; opunha-se à natureza insípida do marido.

Jogos antitéticos são perceptíveis, também, quando da homenagem (prometida por Inácio) na ocasião do nascimento do filho: "o segundo canto" (p. 245): período em que enfrenta a censura da mulher. Carlotinha astutamente intui, então, que o "terceiro" será por ocasião de sua morte. Num jogo oscilatório, vida e morte entrelaçam-se, através da expressão travessa e viva dos olhos "negros e travessos" de Carlotinha, em duelo com o olhar baço e pálido, "branco e velado" de Inácio.

A suposta harmonia do jovem casal, no decorrer do conto, acaba abalada por questões amorosas. O Bruxo do Cosme coloca, em cena, a conhecida estratégia dos romances universais: o triângulo amoroso! E a pista, novamente, surge através de imagens contraditórias dos reflexos do olhar. A chegada de dois estranhos causa um movimento inesperado, uma mudança de focalização. A voz narrativa assim monta o episódio: "voltaram-se todos os olhos e viram duas figuras de homem, um tranqüilo, outro alvoroçado de prazer" (p. 247 - nosso grifo). Surge daí a ameaça de desestabilização e 
desequilíbrio motivada pelo aparecimento de duas figuras indistintas.

A porta, agora, fora aberta... Aberta para Carlotinha conhecer os "olhos do mundo". O acaso estaria ditando as regras? Ou seria predestinação? O pronome indefinido todos, apreendido no excerto, parece reforçar o sentido de indeterminação. Seriam somente Carlotinha e Inácio ou toda a sociedade sob a evidência do triângulo amoroso? Se levarmos em consideração os olhos do casal, seria o desejo suave do retorno ao paraíso a dois, onde tudo parecia calmo e suave? Ou seria, ainda, o fato de todos os indivíduos, egoisticamente, voltarem os olhos para si mesmos. A construção da frase, evidenciaria o sentido reflexivo? Respostas seguras certamente não encontraremos. Estas são tão-somente possibilidades de múltiplas leituras, desafio desse artífice da linguagem.

O período que se anuncia, então, é o de ruptura da ordem estabelecida. No conto, o machete tocado por Barbosa, o forasteiro, assume o valor metafórico do adultério e da luxúria que se conjuga, metonimicamente, com melancolia experimentada pelo jovem esposo. Instaurado o conflito, a melancolia de Inácio avoluma-se, deixando-se transparecer pelas frestas de seus olhos: "se lhe meteu pelos olhos" (p. 251).

Da luta travada, simbolicamente, entre o violoncelo e o machete restava um Inácio saudoso do passado paradisíaco, no convívio de sua Carlotinha: seu Shangrilá perdido nos reflexos do olhar, conforme deixa entrever a voz da enunciação: "contudo a diferença entre o que tinha sido e era agora entrava pelos olhos adentro" (p. 252-3). O infeliz músico expressava, dessa forma, todo seu desgosto em relação ao presente. Também indicava toda sua inveja (in: contra + vid: visão = mau-olhado) pelo sucesso e desprendimento de Barbosa e seu machete. Humilhado, com "olhos no chão" a traduzir o sofrimento, o pobre músico toca, efusivamente, para o filho e, de olhar baixo e perdido, dá-se conta da situação de abandono em que se encontra.

Os olhos de Inácio sempre foram graves demais, restritos demais, bem distintos dos de sua amada. Carlotinha que, em sua meninice travessa, prefere os sonhos de fama, o mundo efêmero e vasto de Barbosa com seu popular cavaquinho. Deixa o marido chorando intimamente, amargando o sofrimento de marido traído. E, no contexto do século XIX, homem não chora, por isso tem ele os "olhos secos" (p. 254). Inácio engole, assim, toda sua dor e enlouquece.

Um outro conto, denominado "Não é o mel para a boca do asno" (Contos Esparsos, 1996), detém certa tonalidade, percebida a partir da expectativa 
de mistérios (desprovida, ainda, da marcante dose de ironia, pessimismo e humor a figurar nas obras posteriores), e do procedimento retórico, a ser condenado mais tarde pelo escritor. Acabando em casamento, o conto, destaca a preservação da honra, porquanto heroína não cede às súplicas de Marques, o que acaba rendendo louros à tradição patriarcal, voltada à moral e aos bons costumes. Pensamento que acaba levando, Marques a ser castigado, posto que se deixara levar pela prostituta Sofia, confirmando a máxima de quem peca deve ser punido.

Não é por coincidência que a protagonista é nomeada por Hortência (do latim, a que cultiva, aponta para sentimentos elevados). Exemplar, “adorável e incomparável" (p. 53) é a moça que possui belos olhos castanhos, observadores, redondos e rasgados, profundos. Segundo o condutor da narrativa: "seus dois olhos castanhos observavam quanto se passava na sala"; sendo que tais olhos "eram rasgados e profundos" (p. 48).

No diálogo do olhar, a moça/deusa escolhe seu preferido: Marques. Este possui “fronte de deus Marte e um olhar de Ganimedes" (p. 48), uma mescla de guerreiro, pois que fronte de Marte, e alegria, já que escolhido de Zeus. A ambigüidade é forte presença no vacilante caráter dessa personagem traduzida em vaidade personificada, a que podemos adicionar: insegurança, infantilidade e frivolidade. Simboliza a essa personagem toda a ideologia paternalista, em que o homem tinha certa licença para o adultério. Por ser frívolo, Marques envolve-se com Sofia, com quem viaja para o Rio da Prata, deixando livre para Meneses o caminho do coração de Hortênsia.

Hortênsia ressente-se com o abandono do noivo. Meneses, jovem taciturno de espírito severo dono de "doloroso olhar" (p. 50), sofre ao presenciar o sofrimento da moça, ao ver "aqueles olhos verterem lágrimas por outro”. Aos poucos, a jovem heroína recupera-se e, segundo o narrador do relato, o seu "olhar apresentava uma serenidade de bom agouro" (p. 55). Enfim, Meneses conquista, de fato, o amor da moça, como que nos informa a voz narrativa: "Com efeito. À proporção que os dias se passavam, sentia ela que um novo sentimento a impelia para Meneses. Ao olhos começavam a falar; as ausências já lhe eram dolorosas; estava no caminho do amor". (p. 56).

Dessa maneira, Meneses e Hortênsia com "olhos fixos um no outro, esquecem-se de si" e passam a sentir a flecha de Eros na direção do amor. Foram os olhos os primeiros a dizer de amor, foram os olhos os primeiros a sentirem falta do ente amado, porque, olhar é luz, luminosidade total: 
aspiração luminosa, pois, parafraseando Denis de Rougemont, quem ama ascende a degraus de êxtase e vive um endeusamento. (1999, p. 51). Foi o que sentiram os dois amantes desse conto.

Em “Primas de Sapucaia!” (Histórias sem data, 1961) transparece, no conto, o tom crítico, perpassado pelo caráter lúdico da linguagem. Enquanto esperava que as primas de Sapucaia (metáfora de contratempo: "febre maligna” - p. 158) saíssem da igreja, nosso protagonista vê passar uma conhecida, uma namorada do passado. Uma antiga aventura que desfilava, naquele dia, frente à igreja, apoiada no delicado "chapelinho de sol", conforme nos indica a voz narrativa.

No deslizar da narrativa, rebuscando suas lembranças, o amante traz Adriana de volta à mente. Embora fosse casada, Adriana ensinara ao jovem rapaz as artimanhas do amor e da traição. Porque frívola, mudava, constantemente, de amantes. De personalidade perversa, segundo a voz da enunciação, podia ser classificada como "namorada do demônio" (p. 157), posto que era "manhosa, injusta, muita vez grosseira" (p. 163), entretanto ardente e amorosa, traduzindo, então, em pura ambigüidade.

O nome da protagonista comporta grande significado. Adriana tem como origem Adria>Adar: deus do fogo, uma das divindades acordadas pelo povo descendente de Teracles. A simbologia aponta, dessa maneira, para uma mulher ardente e poderosa: construção que encontra apoio na tessitura dos olhos modelados à moda machadiana. Conforme nos informa o narrador, a ardente jovem tem "olhos de touro, como os de Juno, grandes e redondos" (p. 156).

Segundo as lendas mitológicas, os olhos de touro são os de Júpiter, que disfarçado de touro, seduz Europa, despertando, assim, os ciúmes de Juno. Ilusão pura na arte do embuste: máscara fantasiosa que desperta ciúmes. É ela a mestra do iludir com "seus grandes olhos de touro e de basilisco" (p. 164). Estes olhos de brilho mortal- fogo e serpente- conotam maldade e têm a capacidade de tirar toda força moral do homem sobre quem recaia seu olhar. Faz um homem abrir mão de seus valores morais, arrasta-o a uma posição humilhante, por não conseguir resistir ao encanto maligno da singular Medusa machadiana.

No exercício intertextual tão caro a Machado, Adriana surge a nos trazer à mente, ainda, a sedutora Virgília. No paralelismo de similitude com a sensual amante de Brás Cubas, podemos destacar que ambas contraíram convenientes casamentos, tornaram-se amantes ardentes e mantiveram 
relacionamento adúltero em uma afastada casinha, usada somente para encontros furtivos. Nelas restam evidente o pecado da luxúria, numa simbiótica relação de anjo e demônio.

Olhos chorosos constróem as primeiras imagens do conto "D. Paula" (Várias histórias, 1977). Os olhos de Venancinha não se contentam pondose sempre a chorar. Os motivos são os ciúmes do marido, que desconfia de traição. A moça tem "olhos cansados de chorar" (p. 173) e também "olhos ternos” (p. 175), apesar de ser leviana. Notemos já o contraste entre essência e aparência. O caráter é duvidoso, a jovem personagem não tem princípios, já que pronta para iniciar novos relacionamentos.

Ciumenta do marido, Venancinha deslumbra-se com o desejo que desperta nos homens, resume em si sentimentos opostos, transita entre luxúria e culpa. Bonita e atraente, embora casada, sai à caça de outras aventuras. Notemos que a escolha do nome da personagem parece Ter sido escolhido propositalmente pelo autor, uma vez que Venâncio, no latim, remete ao que caça. De caçadora, ao mesmo tempo, a moça comporta-se como presa, pois que aparenta sofrimento e ingenuidade estampados no rosto. Atraída pelo olhar magnético de Vasco, a jovem mulher de predador torna-se caça. Vasco é a personagem que participa do triângulo amoroso em que se envolve a aventureira e imatura rapariga delineada pelos matizes artísticos desse mago da literatura.

Uma outra mulher de papel transita, neste conto, pelo trançado de Machado contista é D. Paula: personagem bonita, elegante, embora idosa, dona de um par de olhos grandes, "que deviam ter sido infinitos" (p. 174), pois que "olhos sagazes e teimosos" (p. 175). Segundo o narrador, Paula (do latim: Paulus > de baixa estatura, pequeno), é personagem forte e de grandes olhos, formando um jogo especular de enorme significância. Por ser idosa, nossa protagonista possui o coração, assim como os olhos, (en)cerrados para as aventuras. Cerra também os olhos, negando-se a ver as atitudes levianas da sobrinha, pois que envolve o inocente Conrado (do teutônico: conselheiro, prudente), seu marido, na tarefa de inocentar a jovem.

Nos olhos cerrados de Paula reside a recordação do amor somente realizável através dos casos amorosos da sobrinha. Durante a narração dos namoricos da jovem esposa, D. Paula apresenta-se cheia de vida. Experimenta profunda empatia pelas as histórias da frívola parenta. A boa senhora possui a boca fresca e os olhos, ainda, infinitos para recordar (re+ cordar>cord $>$ coração): recordação camuflada sob o manto da censura 
paternalista. Segundo o narrador, os olhos semicerrados pelas lembranças eram um misto de curiosidade e calor, de ânsia e saudade, esperança e desalento. Era toda a recordação da mocidade inquieta, deslumbrante e palpitante.

Em "Uma senhora" (Histórias sem data, 1961), Machado nos presenteia com D. Camila que, no latim, remete a jovem criada e, também, atendente de cerimonial. O conto monta uma personalidade excêntrica de uma senhora, escrava da aparência, nascida para ser admirada. Vaidosa ao extremo, comparada à deusa da juventude, insiste em conservar o frescor da mocidade. É ela a imagem personificada da futilidade, com seus "olhos castanhos e cálidos" (p. 169), contrastantes com o "olhar sorrateiro de outras damas" (p. 169), talvez de comportamento escuso, segundo as regras vigentes na sociedade da época.

Tais jogos de olhar afagam o ego da personagem D. Camila, porquanto cada mirada significa admiração e devoção, estas transfiguradas pelos olhares famintos, todavia igualmente capazes de consubstanciar a perene juventude. Alguns verbos reforçam a metáfora especular por situarem-se no mesmo campo semântico: olhar, ver, fitar. De fato, os olhos de D. Camila são sentinelas que buscam impedir a passagem do tempo.

Como a madrasta de Branca de Neve mantém o olhar preso ao espelho. Vive em constante sobressalto. Na vida familiar, cada namoro da filha, cada pretendente a genro representa envelhecer. Entretanto a vida segue o rumo Camila acaba por, finalmente, render-se à passagem tempo: torna-se avó. Contudo, não se resigna. Ao contrário, a astuta senhora reverte a situação e, nos extremos cuidados ao neto, assume atitudes de uma jovem e dedicada mãe: num interessante artifício para enganar a si mesmo, o tempo e os outros. Concretiza, desse modo, o sonho do "eternamente jovem".

Na montagem de "Trina e una" (Contos sem data, 1985), aparece a personagem Clara (cuja raiz latina remete à brilhante e ilustre), de "olhos no ar" (p. 147): olhar que vaga indeterminado, seja nas flores ou nos "pingentes do lustre" (p. 150). Esse olhar sem fixez parece demonstrar, por sua vagação, a falta de vontade de prender-se a algo, um não-querer fixar-se nas coisas e nas pessoas, já que o autor atribui à personagem uma personalidade imutável e fechada às novidades.

Segundo a narrativa, Clara é metódica, tem olhos lindos, porém frios e secos, possui, à semelhança da Capitu machadiana, "um olhar oblíquo" (p. 148) mas, contrariamente, sem fulgor. Clara é personagem altamente 
oposta aos semas de seu nome, pois que não comporta a claridade aérea, elevada. Ao contrário, a mulher que freqüenta, habitualmente, a rua da Quitanda aparenta olhos fixos nas pedras da rua. Olhos rentes ao chão, mensageiros da razão. Também de pedra é seu coração, pois embora viúva, não aceita a corte de Garcia e nem de Severiano, pretendentes à mão da viúva. Garcia sempre a espera, na saída da loja, pois quer "gozá-la com os olhos, vê-la andar, pisar de modo régio e tranqüilo" (p. 147). Por outro lado, Severiano $>$ severus $>$ severo e grave parece ser o ideal para Clara, uma vez que apresenta similitude com ela, porquanto também discreto. Engano. Clara também o rejeita. Seu destino é a solidão petréa e dura.

$\mathrm{Na}$ tessitura machadiana, os olhos da protagonista mostram total indiferença em relação à vida amorosa e uma total inaptidão para mudanças. Diante da possibilidade do amor, "os olhos amorteceram-se-lhe um pouco" (p. 149). De fato, Clara está como amortecida > morta para a vida, tamanha sua indiferença: "Os olhos vão de um lado para outro e a cabeça atrás deles, sem ânimo nem vida" (p. 145). Seus olhos vagam perdidos tal qual a alma da mulher-personagem que, no armarinho da cidade, pega as rendas e as "passa [...] pelos olhos, distraidamente [tornando] a cravar os olhos nas pedras da rua" (p. 145). Os olhos, por vezes, "é que tomam a rua" (p. 146), assumindo, metonimicamente, vida própria por sua concretude pétrea e sua vontade férrea, dissociando-se, portanto, da figura sem vida da mulher. A mulher em si não tem atitudes, os olhos adquirem ação, tornado-se, dessa forma, veículos do não desejo da complexa personagem.

Em relação a "O caso da vara" (Contos, 1979), um exemplo de conto ético, o que se destaca, a princípio, é o sentimento de piedade, contudo este é sobrepujado pelo egoísmo, isto é, vencido pelo desejo individual de Damião que, em sua raiz grega, remete a "popular" Sendo povo é a parte mais fraca, por isso, vê-se obrigado a fazer concessões, no intuito de sobreviver e livrarse do seminário. Assim, em nome do interesse pessoal e contra seus próprios sentimentos, acaba por aplicar o castigo na pobre escrava, sua igual.

$\mathrm{Na}$ parte inicial do conto, Damião foge do seminário, onde se nega a permanecer. Procura Sinhá Rita, viúva e amante de João Carneiro, seu padrinho. Acredita que a senhora poderá livrá-lo do seminário, visto que seu "olhar mostrava toda a força da vida" (p. 50). Rita, personagem também desse conto, cujo nome significa duplamente (no grego, é diminutivo de Margarete que, por sua vez, significa margarida e pérola), é forte e ambígua. Seria ela preciosa como a pérola ou admirável como a margarida? 
De acordo com o condutor da narração, "Sinhá Rita tinha quarenta anos na certidão de batismo, e vinte e sete nos olhos. Era apessoada, viva, patusca, amiga de rir: mas, quando convinha, brava como o diabo" (p. 50). A sabedoria conquistada com a idade brindava com a faceirice do olhar jovial, demonstrando, mais uma vez, o oscilar de pólos opostos tão característico do fazer literário de Machado. Avesso no sentido da idealização e da perfeição, suas criaturas transitam, singularmente, entre o bem e o mal, faces de uma mesma moeda.

Damião supõe que Sinhá Rita tenha alguma ascendência sobre João Carneiro. Contudo, este João tão gracioso (hebraico: Yehokhanan > Deus é gracioso), é fraco e cordato, como as ovelhas, já que também Carneiro. Segundo a condução do relato: "João Carneiro estava com a pupila desvairada, a pálpebra trêmula, o peito ofegante. Os olhares que deitava a Sinhá Rita eram de súplica, mesclados de um tênue raio de censura” (p. 51), porquanto tinha consciência de sua debilidade e sabia da incapacidade de livrar o sobrinho da vida religiosa. Apenas, no íntimo, cabia-lhe censurar Rita pelo envolvimento no assunto. Comentário, entretanto, indicado pela expressão do olhar que viera em socorro às palavras que não ousara pronunciar. Importa ressaltar que nesse conto, a força reside nas personagens femininas, relegando aos varões o medo e a fraqueza.

O conto "Carolina" (Contos, 1979), fala, principalmente, de jogos de interesse, ou melhor, dos casamentos feitos por conveniência e interesses pecuniários. Dessa forma, ratifica todo o desprezo do escritor pela sociedade que se sustém movida pelos interesses sociais. Carolina é a jovem de vinte anos que sedutora estimula os "olhos lascivos" (p.45), gulosos e cobiçosos do abastado senhor Mendonça que adquire, como mercadoria, a jovem esposa. Gula, cobiça e luxúria entrelaçam-se no conto, denunciando a ideologia da sociedade paternalista do fim de século.

Em "Conto de escola" (Contos, 1979), os olhos aparecem como metáfora de ação. Interessante é a constituição da personagem Pilar (do espanhol: fonte): menino vivo e esperto, que cabulava as aulas. O perfil lhe remetia a fonte de lucro, ou sabedoria a ser transformada em fonte de lucro? Ambição? De viva inteligência, o menino aprendia rapidamente e com facilidade; ao contrário do que ocorria com Raimundo, filho do professor.

Raimundo, por outro lado, era de inteligência curta, assim como medroso e pálido. Imagem muito distinta do recado dado pelos semas de seu nome que, originário do gótico, portava o sentido de sábio poderoso. Eis 
a ironia: Raimundo não era nem sábio, nem poderoso. Ao contrário, vivia acuado por medo do pai. O menino medroso faz uma proposta a Pilar, oferece moeda em troca de ajuda nas lições. Mas, astutamente, o Bruxo do Cosme Velho coloca no olhar a denúncia da falta, como nos informa o narrador: "Ele deitou os olhos no pai, depois a alguns outros meninos. Um destes, o Curvelo, olhava para ele desconfiado" (p. 26). E o pai do menino era, simbolicamente, a imagem do poder.

Segundo Renato Mezan, "na fantasia da castração, o olho e o olhar têm uma função crucial: ela é imaginada como punição" (1988, p. 459). E o poder, nesse caso, é duplo: pai e professor, num contexto conservador e paternalista. No passado, os pais não necessitavam dizer, bastava-lhes um olhar para que os filhos baixassem os olhos e saíssem das conversas e da sala. A força do olhar significava cega obediência. O pai dominava o filho. O professor dominava os alunos. A relação de superioridade é a mesma.

Reforçando a imagem da força, em Conto de Escola (1979), estava a palmatória, também metáfora maléfica, já que "com seus cinco olhos do diabo" (p. 26). Entre olhares fugidios e furtivos, Raimundo, afinal, oferece dinheiro a Pilar pelo auxílio no estudo. Pilar pende entre a cobiça e o medo. Lança olhar para o mestre, para a classe e afinal cede: "Olhei para o mestre [...]. Relancei os olhos pela sala [...]; deitei-lhe outra vez o olho"(p. 28), acabando por aceitar o pagamento.

O conflito, assim, se instaura porque, conforme deixa clara a narração, Curvelo "tinha os olhos em nós, com um riso que me pareceu mal." (p. 28). Os olhos de Curvelo indicam o insucesso da negociação. A transação é descoberta. O mestre reage, e é assim descrita a visão do terror: "Ele [o mestre] enterrou-me pela consciência adentro um par de olhos pontudos" (p. 28). Tais olhos ferem fundo a alma, traduzindo-se em pavor.

Os meninos são severamente castigados na frente da classe. Os alunos "tinham olhos fixos nos dois". O medo espalhou-se pela sala. Olhares cruzados de Pilar e Curvelo: desejo de vingança. Somente desejo, porém não levado adiante. Na manhã seguinte, sai Pilar a procurar a moeda perdida. Entretanto, seduzido pelo som do tambor dos fuzileiros, deixa-se o menino levar pela marcha cadenciada dos soldados, esquecendo-se da corrupção e da delação, deixando-se envolver pelos sonhos ingênuos e infantis de um menino do Morro do Livramento.

"Missa do galo" (Contos, 1979), traz a história da jovem esposa Conceição, que em noite de Natal encontra-se sozinha sem o marido. Este sai para 
um encontro amoroso. Na casa, a presença de um jovem rapaz perturba a existência da esposa conformada. $\mathrm{O}$ moço se apronta para assistir à missa do galo. Nogueira (de noz > fruto natalino), esse é seu nome, pretendia chegar cedo à igreja, mas deixa-se levar pela atmosfera de sedução, na madrugada daquela noite de Natal.

A protagonista Conceição é (lat.: concepção, imaculada), sedutoramente, construída pela alinhavo poético deste gênio da literatura. No desenho daquela noite especial, Conceição sai do quarto num roupão branco, o que dá um certo ar romântico, uma aparição de deusa na atmosfera natalina. É, entretanto e igualmente, representativa da imagem da solidão no casamento.

A moça possui temperamento moderado, sem extremos, sem muitas lágrimas, nem sorrisos. O olhar, esta porta aberta da alma, denuncia, entretanto, uma outra Conceição: mais dissimulada e lânguida. Segundo a descrição do autor: "Os olhos dela não eram bem negros, mas escuros, ar interrogativo” (p. 82). A aparência era de negros, porém não era o que aparentavam. Assim como Conceição. Nas entrelinhas do mestre do romance brasileiro, perdura o constante jogo entre essência e aparência tão caro à prosa desse mestre da literatura.

Os jovens encontram-se sozinhos no cômodo neutro e principal da casa. A conversa na sala inicia-se. Quando o assunto é sobre casamento, já a mulher não mostra mais os olhos compridos da conversação lânguida dos dois. Apresenta, outrossim, um "olhar vago" a olhar à toa para as paredes. Indício que o casamento ia mal. Muitas vezes, durante a conversação, a jovem senhora parece dormir; "mas os olhos cerrados, por um instante, abriram-se logo sem sono nem fadiga, como se ela os houvesse fechado para ver melhor" (p. 84), para perceber melhor o que acontecia: perceber-se como mulher ardente e sedutora, capaz de despertar sensações.

Na montagem aparentemente paradoxal, a sugestão é de sedução, apresentada pela languidez da cena: o élan envolve o casal. A atmosfera amorosa é sugerida pela construção das ações oculares da protagonista. $\mathrm{O}$ olhar de Conceição exerce sobre Nogueira certo magnetismo, pois este "fazia esforço para arredar os olhos dela" (p. 85), mas, quando dava por si, estava prisioneiro dos olhos da mulher.

No silêncio dos olhares, nos intervalos, um tênue véu de mistério induz à insinuação de sedução: adultério, ou antes, ao desejo deste. Uma insinuação 
traduzida por olhos que passeiam, que fitam ou, que meio cerrados, permitem que descubramos o mais íntimo segredo da personagem: sentir-se mulher ainda desejada, numa sociedade em que somente o desejo masculino abria espaço.

\section{Considerações Finais}

Importa deixar claro que lançamos apenas um olhar sobre a questão. Tais considerações estão longe de fechar o assunto, outras leituras serão, certamente, efetuadas. Outros pesquisadores lançarão novos olhares e outros ângulos serão analisados. Entretanto, faz-se necessário certo arremate no estudo. Não a costura final, mas um ajuste na bainha, talvez. Uma proposta de síntese? Uma possibilidade de arrumação apenas, para o que fora colocado a respeito da tessitura do olhar nas tramas do Bruxo do Cosme Velho.

Esses olhos, metáfora e metonímia, muito dialogaram no percurso da narrativa. E, no diálogo do olhar, jogos antitéticos evidenciam encanto e desencanto; amor e ódio; alegria e tristeza; vida e morte. Olhares enigmáticos e dissimulados, serenos e fulgurantes, enganadores e agudos, cortantes como punhal e suaves como a cálida tarde emolduram a cena da moderna sociedade brasileira. $\mathrm{O}$ escritor não se deteve na cor dos olhos de suas criaturas de papel, tampouco, se tais faróis luminosos habitaram rostos masculinos ou femininos. Ressaltou-os, de fato, como espelhos da alma humana, como olhos-discurso a escrutinar segredos da alma humana, ratificando, mais uma vez, a genialidade desse mago da linguagem chamado Joaquim Maria MACHADO DE ASSIS.

\section{Referências Bibliográficas}

1 - Contos

MACHADO DE ASSIS, Joaquim Maria. "Não é o mel para a boca do asno”. In:_Contos esparsos. Organização e prefácio de Raimundo Magalhães Júnior. 3a. ed. Rio de Janeiro: Ediouro, 1996, p. 47-60.

. "O machete”. In: _- Contos/uma antologia. Seleção, introdução e notas de John Gledson. São Paulo: Companhia das Letras, 1998, p. 241-254.

. “Trina e una”. In:_Contos sem data. Organização e prefácio de Raimundo Magalhães Júnior. Rio de Janeiro: Ediouro, 1985, p. 145-151. 
. "Conto de escola"; "Carolina"; "O caso da vara"; "Missa do galo". In: Contos. Seleção de Deomira Stefan. 7ª ed. São Paulo: Ática, 1979, p. 25-30; p. 45-48; p. 49-53; p. 81-85 (Série Bom Livro).

. "D. Paula”. In: __ Várias histórias. 2. ed. Rio de Janeiro: Civilização Brasileira; Brasília: INL, 1977, p. 173-182.

"Primas de Sapucaia!" e "Uma senhora”. In:__ História sem data.

São Paulo: Brasileira; Rio de Janeiro: Livro do Mês, 1961, p. 149-164; p. 167180, v. 13 (Obras Completas de Machado de Assis).

2 - Outros

FLAUBERT, Gustave. Madame Bovary. São Paulo: Abril Cultural, 1970, v. 3 (Imortais da Literatura).

GOMES, Eugênio. O enigma de Capitu: ensaio de interpretação. Rio de Janeiro: José Olympio, 1967 (Coleção Documentos Brasileiros).

MACHADO DE ASSIS. D. Casmurro. São Paulo: Abril Cultural, 1971, p. 177-346, v. 16 (Imortais da Literatura).

MEZAN, Renato. “A Medusa e o telescópio”. In: NOVAES, Adauto. O olhar. São Paulo: Companhia das Letras, 1988, p. 445-477.

ROUGEMONT, Denis de. O amor e o ocidente. Tradução de Anna Hatherly. $2^{\text {a }}$. ed. Lisboa: Vega, 1999.

SARAIVA, Juracy. "Incidências do olhar em D. Casmurro". Disponível: http://www.geocities.com/ail_br/html. Acesso em 06 jun. 2002.

Recebido em 26 de novembro de 2007

Aceito em 27 de fevereiro de 2008 